\title{
COLONIZATION PREVALENCE AND SUSCEPTIBILITY OF STREPTOCOCCUS AGALACTIAE IN PREGNANT WOMEN AT HUSM
}

\author{
Adriane Regina Veit* \\ Rosmari Horner** \\ Magda Cristina Souza Marques Roehrs** \\ Leticia Eichstaedt Mayer** \\ Silvana Oliveira Santos** \\ Rosieli Martini** \\ Maísa Kräulich Tizotti** \\ Cláudia Barbisan Kempfer** \\ Vanessa Rodrigues Martins** \\ Lisete Fronza** \\ Melissa Dias Costa Cunha** \\ Paola Roehrs Colpo** \\ Cristine Kolling Konopka**
}

\begin{abstract}
The Streptococcus agalactiae colonization prevalence and its susceptibility to antimicrobials in pregnant women at University Hospital of Santa Maria (HUSM) were evaluated from June to December 2009. The vaginal-rectal material was inoculated into tubes containing Todd-Hewitt broth with subsequent subculture on blood agar. The GBS identification was made through presumptive tests, confirmed by serological test and its susceptibility was evaluated. The occurrence of GBS maternal-fetal transmission in the colonized pregnant women was researched. The GBS colonization was $11.11 \%$. All strains were susceptible to penicillin, ampicillin, and vancomycin. Two strains $(50 \%)$ were intermediate to clindamycin and one (25\%) intermediate to erythromycin. A newborn whose mother was colonized had early-onset neonatal infection by GBS. By this, it is very important the research about the colonization by GBS in all pregnant women from 35 to 37 weeks of gestation and the use of intrapartum antibiotic prophylaxis for colonized pregnant women.
\end{abstract}

Descriptors: Streptococcus agalactiae; Prevalence; Pregnant women; Newborns; Microbial Sensitivity Tests.

\section{RESUMO}

Avaliou-se a prevalência de colonização pelo Streptococcus agalactiae e o seu perfil de sensibilidade frente aos antimicrobianos em gestantes no Hospital Universitário de Santa Maria (HUSM), de junho a dezembro de 2009. O material vaginal-retal foi inoculado em tubos contendo caldo Todd-Hewitt com posterior subcultura em ágar sangue. A identificação do EGB foi realizada através de testes presuntivos, confirmadas por teste sorológico e avaliado seu perfil de sensibilidade. Pesquisou-se ocorrência de transmissão materno-fetal do EGB nas gestantes colonizadas. A prevalência de colonização foi de $11,11 \%$. Todas as cepas foram sensíveis à penicilina, ampicilina e vancomicina. Duas cepas (50\%) foram intermediárias à clindamicina e uma $(25 \%)$ intermediária à eritromicina. Um recém-nascido de mãe colonizada teve infecção neonatal de início precoce por EGB. Confirma-se a importância da pesquisa de colonização por EGB em todas as gestantes entre $35^{\mathrm{a}}$ e $37^{\mathrm{a}}$ semana de gestação e uso de quimioprofilaxia intraparto nas gestantes colonizadas.

Descritores: Streptococcus agalactiae; Prevalência; Gestantes; Recém-nascido; Testes de Sensibilidade Microbiana.

\section{INTRODUCTION}

Streptococcus agalactiae or group B streptococcus (GBS) is a normal inhabitant of the gastrointestinal tract and may colonize the vagina chronically or intermittently in about a third of women. The colonized pregnant women are usually asymptomatic, but the GBS is responsible for $2-4 \%$ of urinary infections during pregnancy. ${ }^{1}$ In pregnancy and puerperium this colonization may compromise the amnion, endometrium and abdominal wall, leading to abortion and prematurity. 2,3

Around 50 to $75 \%$ of neonates exposed to GBS intravaginal become colonized and 1 to $2 \%$ of all newborns of positive mothers will develop early-onset invasive disease. ${ }^{4-6}$ Neonatal invasive infections by

\footnotetext{
* Estudante do curso de Farmácia, bolsista de iniciação científica no Laboratório de Bacteriologia do Departamento de Análies Clínicas Toxicológica do Centro de Ciêncis da Saúde da UFSM

** Universidade Federal de Santa Maria
} 
S. agalactiae are more common than other well-known neonatal diseases such as rubella, syphilis and spina bifida. $^{1}$

Systemic infection by GBS has two manifestations in the newborn: a) the early-onset disease, which derives from vertical transmission or through the aspiration of contaminated amniotic fluid ${ }^{4,7}$, and it manifests itself in the first 24 hours of life, causing pneumonia, sepsis, and, less commonly, meningitis ${ }^{1,8,9}$ and $b$ ) the late-onset disease, which manifests itself from 7 days to 12 weeks of life and it may be of maternal or nosocomial origin and characterized mainly by meningitis. ${ }^{1}$ Neurological sequelae occur in approximately $30-50 \%$ of meningitis survivors. ${ }^{49}$

The presence of maternal colonization prevalence between 15 and $25 \%$ places Brazil in a level of concern when considering the possibility that high rates of earlyonset neonatal infection are occurring without being identified, ${ }^{10}$ as there are no manuals or technical recommendations on the theme in the country. ${ }^{11}$

Our objective was to assess the prevalence of vaginal and/or rectal colonization by $S$. agalactiae and its susceptibility to antimicrobials in pregnant women from 35 to 37 weeks of gestation who were treated at University Hospital of Santa Maria (HUSM) in Santa Maria, RS.

\section{MATERIAL AND METHODS}

This is a cross-sectional, prospective and retrospective, active and passive study in which we assessed the colonization prevalence and susceptibility of GBS in 36 pregnant women treated at the Obstetric Center (OC) of HUSM from June to December 2009. The study included women from 35 to 37 weeks of gestation +6 days with intact membranes. The exclusion criteria were the presence of vaginitis, AIDS, HIV positive and who received antimicrobial therapy in the last 15 days.

The participants were informed about the objectives and procedures of the study and signed a consent form. The study was approved by the Ethics Committee on Human Beings of the Federal University of Santa Maria (UFSM) in May 2008, under number 0235.0.243.000-08.

The sample collection was performed by the team of HUSM OC, following the guidelines of the Centers for Disease Control and Prevention (CDC). ${ }^{1}$ With sterile swabs samples were collected vaginal (vaginal opening) and a rectal examination (insertion of the swab through anal sphincter) and inoculated separately into two test tubes containing Todd-Hewitt selective broth medium plus gentamicin $(8 \mu \mathrm{g} / \mathrm{mL})$ and nalidixic acid $(15 \mu \mathrm{g} / \mathrm{mL})$. All samples were properly identified and sent to the Laboratory of Bacteriology, Building 26, Room 1201, Center for Health Sciences, Department of Clinical and Toxicological Analysis of UFSM to be processed.

The selective broths were incubated in a $5 \% \mathrm{CO}_{2}$ for 18 to 24 hours at $35 \pm 2^{\circ} \mathrm{C}$ and subcultured on blood agar under the same conditions of incubation. After 24 hours, the plates were identified as suggestive of S. agalactiae by colonial morphology (gray, surrounded by a discrete halo of hemolysis total, non-hemolytic or alpha-hemolytic), Gram stain (gram positive), ability to produce catalase (catalase negative), bile esculin (negative) and CAMP factor (positive). For confirmation, serology was performed using the latex agglutination with PASTOREX ${ }^{\mathrm{TM}}$ STREP kit (Bio$\mathrm{Rad})$.

The antimicrobial susceptibility of isolates was performed using disc diffusion method, as recommended by the Clinical and Laboratory Standards Institute (CLSI, 2010). ${ }^{12}$ We tested the antibiotic ampicillin, cefotaxime, clindamycin, erythromycin, levofloxacin, penicillin and vancomycin.

For the research on the inducible resistance to clindamycin to be made, erythromycin and clindamycin disks were placed at a distance of $20 \mathrm{~mm}$ disc to disc (Test D). The positivity of this test is viewed by the flattening of the halo of clindamycin.

When there was a confirmation of maternal colonization by $S$. agalactiae, a passive assessment was made with the records in order to detect the occurrence of early-onset or late-onset neonatal infection in these women's newborns through positive blood culture and/or cerebrospinal fluid (CSF) and the evolution of this patient was assessed.

\section{RESULTS}

From 36 women included in the study, four of them had vaginal and/or rectal culture GBS-positive, 
resulting in a prevalence of $11.11 \%$. Tests for the presumptive identification of $S$. agalactiae in these women are depicted in Table 1.

The antimicrobials tested are listed in Table 2 with the group which they belong, according to CLSI 2010: Group A (first choice, tested and reported in the routine), group B (first choice, tested and reported selectively, especially important agents in nosocomial infections), group C (additional and reported selectively, alternative agents when there are strains resistant to multiple primary drugs). All of them showed $\mathrm{D}$ test negative.

TABLE 1 - Tests results for S. agalactiae identification in colonized pregnant women

\begin{tabular}{cccccc}
\hline Pregnant Woman $\left(\mathrm{n}^{\mathrm{o}}\right)$ & Catalase & Bile esculin & Hemolysis & CAMP & Serology \\
\hline 5 & - & - & $\beta$ & - & + \\
7 & - & - & $\beta$ & - & + \\
34 & - & - & $\beta$ & + & + \\
35 & - & - & y & - & +
\end{tabular}

(+) positive; (-) negative

TABLE 2 - Susceptibility to antimicrobials of four pregnant women with culture vaginal and/or rectal GBS-positive

\begin{tabular}{cccccccc}
\hline Pregnant woman $\left(\mathrm{n}^{\circ}\right)$ & AMP (A) & CTX (B) & CLI (A) & ERI (A) & LEV (C) & PEN (A) & VAN (B) \\
\hline 5 & $\mathrm{~S}$ & $\mathrm{~S}$ & $\mathrm{I}$ & $\mathrm{I}$ & $\mathrm{S}$ & $\mathrm{S}$ & $\mathrm{S}$ \\
7 & $\mathrm{~S}$ & $\mathrm{~S}$ & $\mathrm{I}$ & $\mathrm{S}$ & $\mathrm{S}$ & $\mathrm{S}$ & $\mathrm{S}$ \\
34 & $\mathrm{~S}$ & $\mathrm{~S}$ & $\mathrm{~S}$ & $\mathrm{~S}$ & $\mathrm{~S}$ & $\mathrm{~S}$ & $\mathrm{~S}$ \\
35 & $\mathrm{~S}$ & $\mathrm{~S}$ & $\mathrm{~S}$ & $\mathrm{~S}$ & $\mathrm{~S}$ & $\mathrm{~S}$ & $\mathrm{~S}$ \\
\hline
\end{tabular}

$\mathrm{AMP}=$ ampicillin, $\mathrm{CTX}=$ cefotaxime, $\mathrm{CLI}=$ clindamycin, $\mathrm{ERI}=$ erythromycin,

$\mathrm{LEV}=$ levofloxacin, $\mathrm{PEN}=$ penicillin, $\mathrm{VAN}=$ vancomycin.

$\mathrm{S}=$ Susceptible, I = Intermediate.

In a newborn whose mother was colonized with GBS the occurrence of early-onset neonatal infection was observed. The baby was born with prematurity and prolonged delivery, he needed resuscitation and he was transferred to ICU. He was diagnosed with meningitis caused by S.agalactiae, isolated from blood culture and CSF, and he was treated with ampicillin (1/40 16mL IV 12/12h) and gentamicin (40/20 $5.5 \mathrm{~mL}$ IV 24/24h). He was discharged after 18 days.

\section{DISCUSSION}

Among the tests performed according to conventional methodology for identification of GBS, the CAMP test is one of the most sensitive. ${ }^{13}$ This test is based on production of a diffusible hemolysin by most strains of GBS, which together with other hemolysin produced by Staphylococcus aureus ?-hemolytic strains
(ATCC 25923) causes complete lysis of red blood cells from blood agar plate and produces a characteristic zone of hemolysis in the form of arrowheads, called factor CAMP.6,13 In our tests only one sample was positive for the presence of CAMP factor, demonstrating a low sensitivity for identifying GBS isolated in this study. Other identification tests had results which were consistent with the literature. ${ }^{13}$

The prevalence of maternal GBS colonization varies from 5 to $40 \%$ concerning some factors such as the gestation period in which cultures are performed, the collection site, the bacteriological methods used to detect GBS and the origin and characteristics of the population studied. ${ }^{1,2,10}$

In this study we chose to search GBS both vaginal and rectal sites, as there are reports that the colonization rate increases from 5 to $25 \%$ when the 
sample is collected in more than one site. ${ }^{1}$ Simões et al. (2007) demonstrated that $56.5 \%$ of colonized pregnant women would not be identified if there was only the rectal sample, and in case of only vaginal sample, in $20 \%$ of women this colonization would not be diagnosed..$^{14}$

Since 2002, the CDC emphasizes the universal search for GBS colonization rather than the protocol based on risk factors, once studies showed that this strategy was more effective to define the use of intrapartum chemoprophylaxis, especially taking into account that many colonized pregnant women did not have risk factors for newborn infection. ${ }^{15,14,15}$

In this context, studies that evaluate the rate of GBS colonization have been performed worldwide and the prevalence rates are variable: $8.6 \%$ in Mexico in $1999 ; 1610.6 \%$ in Turkey in $2000,{ }^{17} 9.1 \%$ in Iran in $2003,57.6 \%$ in Argentina between 2004 and 2006. ${ }^{18}$

In Brazil, these rates have become even higher. In a study conducted between 2002 and 2003, in a public maternity hospital in Londrina - Paraná, a prevalence of $14.9 \%$ was found. ${ }^{2}$ Another one conducted in the same period in Florianopolis - Santa Catarina presented a GBS colonization of $21.6 \% .{ }^{19}$ In Rio de Janeiro prevalence rates of $19.2 \%$ were found from 2003 to $2004 .^{20}$ A study accomplished at the Center for Integral Attention to Women's Health at the University of Campinas in 2003 and 2004 found the rate of maternal GBS colonization of 27.6\%. ${ }^{6}$ In São Luis - Maranhão, the prevalence was $20.4 \%$ from 2005 to $2006 .^{10}$ The present study showed a colonization rate of slightly lower than the national ones (11.11\%).

The currently recommended prophylaxis for the prevention of neonatal disease is the use of intrapartum antibiotics only for women colonized by GBS. CDC indicates penicillin as the first choice drug for intrapartum antibiotic prophylaxis (5 million U IV then 2.5 million $U$ 4/4h until delivery) and treatment of neonatal infection by $S$. agalactiae (200 to 500,000 $\mathrm{U} / \mathrm{kg} /$ day) in association with gentamicin.,21,22 Ampicillin can be used alternatively. Erythromycin and clindamycin are the drugs of choice for prophylaxis in women colonized by GBS who are allergic to penicillin. ${ }^{1}$

Although most strains are susceptible to penicillin, $14,15,20,23,24$ the increased use of erythromycin and clindamycin in patients allergic to penicillin or for the prevention and treatment of other infections, has shown growth rates of GBS resistance to these antimicrobial agents in many countries, including Brazil. 15,20

A study made from 1994 to 1999 in Rio de Janeiro found in colonized women $5.4 \%$ and $1.1 \%$ of GBS resistance to erythromycin and clindamycin, respectively. ${ }^{25}$ But in recent years the GBS resistance rates to these antibiotics have steadily been increasing in colonized women. In 2003-2004 Borger et al. found $9.4 \%$ resistance of $S$. agalactiae to erythromycin and $6.2 \%$ to clindamycin. ${ }^{20}$ Costa et al., in 2005-2006, found rates of 23.6 and 25.4\%10 and Castellano-Filho et al., in 2007-2008, found $22.7 \%$ and 50\% resistance to erythromycin and clindamycin, respectively. ${ }^{15}$

In relation to susceptibility of four pregnant women colonized by GBS in the present study, we found no resistance to the tested antimicrobials. All pregnant women were susceptible to penicillin and ampicillin, suggesting that intrapartum antibiotic prophylaxis of first choice in patients who are not allergic would have satisfactory results in our hospital. Two pregnant women presented an intermediate profile to clindamycin and one did the same to erythromycin. This reflects a reduction of GBS susceptibility to these antibiotics and intensifies attention to its use, especially in patients who are allergic to penicillin, since for the latter ones the usual doses of these antibiotics may be ineffective in intrapartum antibiotic prophylaxis.

Even with the CDC recommendations, many cases of early-onset neonatal infection still occur in our midst. In Porto Alegre - Rio Grande do Sul was found an incidence of early-onset neonatal GBS infection of $1 / 1000$ born alive ${ }^{26}$ while in Campinas - Sao Paulo, a higher incidence of 10.3/1000 born alive was found. ${ }^{6}$

The presence of one case of early-onset neonatal infection among four colonized pregnant women reflects the occurrence of GBS maternal-fetal transmission in our center. This reinforces the necessity of implementing a program for prevention of GBS infection including the detection of colonization during the 35-37 weeks of pregnancy as a fundamental test of prenatal care, besides that obstetricians should join this case due to its great importance. 


\section{CONCLUSION}

The high frequency of GBS colonization, the increase in resistance to certain antibiotics recommended by the $\mathrm{CDC}$ and the occurrence of neonatal GBS infection in our population underscores the importance of the survey of $S$. agalactiae colonization and their antimicrobial susceptibility during 35-37 weeks of gestation. This leads to a rational choice of antimicrobial agent to be used in the antibiotic prophylaxis of pregnant women known to be colonized, it also reduces the unnecessary use of intrapartum antibiotic prophylaxis when it is based only on risk factors, in addition preventing GBS maternalfetal transmission.

\section{REFERENCES}

1. Schrag S, Gorwitz R, Fultz-Butts K, Schuchat A. Prevention of perinatal group B streptococcal disease. Revised guidelinesa from CDC. Morbidity and Motality Weekly Report. 2002; 51(RR-11): 1-22.

2. Beraldo C, Brito ASJ, Saridaki HO, Matsuo T. Prevalência da colonização vaginal e anorretal por Estreptococo do grupo B em gestantes do terceiro trimestre. Rev Bras de Ginecol Obstet. 2004; 26(7): 543-9.

3. Reyna-Figueroa J, Ortiz-Ibarra FJ, Pérez-Antonio B, Navarro-Godínez S, Casanova-Román G, García-Carrilo LE. Quimioprofilaxis para evitar la colonización materna por estreptococo grupo B. Consecuencias de no adoptar la recomendación internacional. Salud Pub Mex. 2008; 50(2): 155-61.

4. Quentin R, M, Watt S. Prise en charge de Streptococcus agalactiae en obstétrique. J Gynecol Obstet Biol Reprod. 2002; 31(2): 4S65-73.

5. Jahromi BN, Poorarian S, Poorbarfehee S. The Prevalence and Adverse Effects of Group B Streptococcal Colonization during Pregnancy. Arch Iranian Med. 2008; 11(6): 654-7.

6. Nomura ML, Passini Jr R, Oliveira UM, Calil R. Colonização materna e neonatal por estreptococo do grupo B em situações de ruptura pré-termo de membranas e no trabalho de parto prematuro. Rev Bras de Ginecol Obstet.2009; 31(8): 397-403.

7. Stus M, Pawlik D, Brzychczy-Wloch M, Gosiewski T, Rytlewski K, Lauterbach R, et al. Group B streptococcus colonizations of pregnant women and treir children observed on obstetric and neonatal wards on the University Hospital in Krakow, Poland. J Med Microbiol. 2009; 58: 228-33.

8. Backer CJ, Morven ES. Group B streptococcal infetions. In: Remington JS, Klein JO, editors. Infectious disease of the fetus and the newborn infant. 5 th ed. Philadelphia: Sanunders. 1998 : 1091-156.

9. Beitune P, Duarte G, Maffei CML. Colonization by Streptococcus agalactiae during pregnancy: maternal and perinatal prognosis. . Braz J Infect Dis. 2005; 9(3): 276-82.

10. Costa ALR, Lamy Filho F, Chein MBC, Brito LMO, Lamy ZC, Andrade KL. Prevalência de colonização por estreptococos do grupo B em gestantes atendidas em maternidade pública da região Nordeste do Brasil. Rev Bras de Ginecol Obstet. 2008; 30(6): 274-80.

11. Amaral E. Estreptococo do grupo B: rastrear ou não rastrear? Eis a questão. Rev Bras de Ginecol Obstet. 2005; 27(4):165-7.

12. Clinical and Laboratory Standards Institute (CLSI). Performance standards for antimicrobial susceptibility testing, nineteenth information supplement, document M100-S20. Wayne, Pensylvania, USA: CLSI, 2010.

13. Koneman, diagnóstico microbiológico: texto e atlas colorido/Washington C. Winn Jr. [et al.] ; revisão técnica Eiler Fritsch Toros ; tradução Eiler Fritsch Toros [et al.]. 6. ${ }^{\text {a }}$ ed. Rio de Janeiro: Guanabara Koogan; 2008.

14. Simões JA, Alves VMN, Fracalanzza SEL, Camargo RPS, Lenir M, Milanez HMBP, et al. Phenothypical characteristics of Group $B$ streptococcus in parturients. Braz J Infect Dis. 2007; 11(2): 264-6.

15. Castellano Filho DS, Silva VL, Nascimento TC, Vieira MT, Diniz CG. Detection of group B Streptococcus in Brazilian pregnant women and antimicrobial susceptibility patterns. Braz J Microbiol. 2010; 41: 104755.

16. Ocampo-Torres M, Sânches-Pérez HJ, NazarBeutelspacher A, Castro-Ramíres AE, Cordero-Ocampo B. Factores asociados a la colonización por Streptococcus del grupo B en mujeres embarazadas de Los Altos, Chiapas. Salud Pub Mex. 2000; 42(5): 413-21.

17. Arisoy AS, Altinisik B, Tünger Ö, Kurutepe S, Ispahi Ç. Maternal carriage and antimicrobial resistance profile of 
group B Streptococcus. Infection. 2003; 31(4): 244-6.

18. Quiroga M, Pegels E, Oviedo P, Pereyra E, Vergara M. Antibiotic suscetptibility patterns and prevalence of group B Streptococcus isolates from pregnant women in Missiones, Argentina. Braz J Microbiol. 2008; 39(2): 24550 .

19. Pogere A, Zoccoli CM, Tobouti NR, Freitas PF, D'Acampora AJ, Zunino JN. Prevalência da colonização pelo estreptococo do grupo $\mathrm{B}$ em gestantes atendidas em ambulatório de pré-natal. Rev Bras de Ginecol Obstet.2005; 27(4): 174-80.

20. Borger IL, D'Oliveira REC, Castro ACD, Mondino SSB. Streptococcus agalactiae em gestantes: prevalência de colonização e avaliação da suscetibilidade aos antimicrobianos. Rev Bras de Ginecol Obstet. 2005; 27(10): 575-9.

21. Harrison, Medicina Interna - Compêndio; $14^{\mathrm{a}}$ ed. - Rio de Janeiro: McGraw-Hill Interamericana do Brasil Ltda, 1998.

22. Cecil, Tratado de medicina interna/ editado por Lee Goldman, Dennis Ausiello; [tradução de Ana Kemper... et al.] . - Rio de Janeiro: Elsevier, 2005.

23. Rodríguez-Morales AJ, Rodríguez- Cruz N, García A, Pastran B, Jiménez I, Meijomil P. Antimicrobial Activity of Certain Drugs against Streptococcus agalactiae Strains in a General Hospital of Caracas, Venezuela 1997-2003. Acta Cient Estud. 2007; 5(3): 115-8.

24. Joaquim A, Matee MI, Massawe FA, Lyamuya EF. Maternal and neonatal colonisation of group $B$ streptococcus at Muhumbili National Hospital in Dar ES Salaam, Tanzania: prevalence, risk factors and antimicrobial resistence. BMC Public Health. 2009 9(437). Disponível em: http://www.biomedcentral.com/14712458/9/437.

25. D'Oliveira REC, Barros RR, Mendonça CRV, Teixeira LM, Castro ACD. Susceptibility to antimicrobials and mechanisms of erythromycin resistance in clinical isolates of Streptococcus agalactiae from Rio de Janeiro, Brazil. J Med Microbiol. 2003; (52): 1029-30.

26. Miura E, Martini MC. Group B Streptococcal neonatal infections in Rio Grande do Sul, Brazil. Rev Inst Med Trop São Paulo. 2001; 23(5): 243-6.
Endereço para correspondência:

Adriana Regina Veit

Rua Marechal Floriano Peixoto n.1367 ,apt 206. Bairro Centro. Santa Maria

E mail: adriane.veit@hotmail.com

Recebido em 15 de dezembro de 2010.

Aprovado em 10 de janeiro de 2011. 